\title{
Search for the Principles of Architectural and Spatial Organization of a Residential Quarter in the Research of Soviet Architects in the 1930s
}

\author{
Yulia Starostenko ${ }^{1, *}$
}

\begin{abstract}
${ }^{1}$ Scientific Research Institute of Theory and History of Architecture and Urban Planning (NIITIAG), Branch of the Federal State Budget Institution "Central Scientific-Research and Project Institute of the Construction Ministry of Russia", Moscow, Russia

*Corresponding author. Email: ystarostenko@yandex.ru
\end{abstract}

\begin{abstract}
The article provides an overview of the searches made by Soviet architects while working on the problem of designing a residential quarter in the 1930s. Among the factors that influenced these searches, the problem of mass residential construction for the needs of industrialization, the idea of "collectivization of the way of life" (obobshchestvleniye byta) and the course on "mastering of historical heritage" (osvoyeniye istoricheskogo naslediya) are considered. By the analysis of research materials of Soviet architects, the article identifies two directions of the search for the principles of architectural and spatial organization of blocks. One of them is associated with the development of a regulatory framework governing the design of residential development, the other — with the search for compositional methods for solving this development. The special attention article pays to the search conducted by architects in these two directions; an analysis of the requirements to which the architectural and spatial organization of the quarter was to comply; it is trace how the complexity of these requirements gradually influenced to the search for Soviet architects.
\end{abstract}

\section{Keywords: Soviet town planning, Soviet architecture, residential quarter, architectural and spatial}

organization of a residential quarter, line building, ribbon building, 1930s

\section{INTRODUCTION}

The problem of the architectural and spatial organization of a residential quarter in the USSR in the 1930 s very little studied. It never became the object of special historical research, although the development of the problem of designing a residential quarter as an applied problem went on continuously in the USSR since the 1930s. In the historical aspect, this problem was mentioned in the writings of Russian architectural historians (S.O. Khan-Magomedov, V.E. Khazanova, M.G. Meerovich and others) in connection with the discussion about the socialist settlement of the border the 1920 s - 1930s, but, as a rule, it came down to stating the use of a method of building in the description of town planning projects. Exceptions include articles by E.V. Konysheva devoted to the planning evolution of the quarter in the projects of socialist towns in the late 1920 s - early 1930 s and the introduction of foreign experience for solving the

*This paper was funded by the Program of Fundamental Researches of the Ministry of Construction, Housing and Utilities of the Russian Federation and the Russian Academy of Architecture and Construction Sciences 2020, the Research Project 1.2.19. problem of a residential quarter in the early 1930s [1, 2], as well as articles by A.V. Vasilyeva about the features of the residential buildings organization in Moscow and Leningrad in that period [3, 4]. Researchers involved in Soviet architecture and town planning in the mid to second half of the 1930s (N.N. Bronovitskaya, Yu.P. Bocharov, Yu.L. Kosenkova, and others) also usually focused only on projects planning of Soviet cities as a whole, or projects of individual buildings. The scientific research works of Soviet architects of the 1930s, in which the principles of the architectural and spatial organization of a residential quarter were developed at a theoretical level, still remain unexplored. This article is intended to fill this gap.

\section{SOVIET TOWN PLANNING AT THE TURN OF} THE 1920S - 1930S: TASKS AND PROBLEMS

The development of town planning in the USSR in the late 1920 s - early 1930 s was determined by a number of factors. The course towards industrialization required high rates of construction not only of industrial structures, but also of residential buildings for builders 
and future workers of this factories and plants. In some cases, for example, in the Urals, it was about creating completely new cities next to new factories, in others - about creating new areas on the outskirts of existing cities. And in these conditions, the development of the principles of designing mass residential development was of great importance.

An important factor to consider in this work was the idea of collectivization of the way of life. Radical variants of the "immediate and complete" collectivization of the way of life were condemned in May of 1930 in a decree of the Central Committee of the All-Union Communist Party of Bolsheviks "On Work at the Reconstruction of the Way of Life", but the same decree ordered "during the construction of workers' settlements" "to provide for the equipment of these settlements... by baths, laundries, public canteens, children's institutions, clubs, schools and medical care" [5]. The resolution referred to the construction of settlements at new large enterprises, but these guidance became fundamental in the design of the all residential development in the USSR. A year later, the task of deliberate placement of cultural and consumer services enterprises in residential buildings was emphasized in the resolution of the June Plenum of the Central Committee of the All-Union Communist Party of Bolsheviks, 1931, “On Moscow's Urban Services and the Development of the Urban Services of the USSR".

In January 1932, according to the report of L.M. Kaganovich The III Moscow regional and II city conferences of the All-Union Communist Party of Bolsheviks adopted a decision on the priority construction of the capital's avenues, which marked increased attention to the artistic design of Soviet cities. A month later, at the end of February 1932, the results of the competition for the project of the Palace of Soviets set a new vector for the development of Soviet architecture associated with the "mastering of historical heritage". These changes were reflected also in Soviet urban planning, where the issue of ensemble and "ensemble development" took a special place. Planners were urged "not to be afraid of panic that you will do something similar to the good old, even if it is good in the context of classical solutions", "not to ignore purely picturesque decorative methods, without compromising to functionality and the economy, of course", "not to be afraid of the classical symmetry axis" [6].

This diversity of requirements that predetermined two directions of searching for the principles of the architectural and spatial organization of the residential quarter in the studies of Soviet architects in the 1930s. One was associated with the development of a regulatory framework governing the design of residential buildings, the other - with the search for compositional methods for this development.

\section{DEVELOPING A REGULATORY FRAMEWORK: FROM RESEARCH TO TRYING TO CREATE A SINGLE STANDARD}

The first Soviet book in which was made an attempt to formulate the principles of the architectural and spatial organization of a residential quarter was the book by P.I. Goldenberg and V.I. Dolganov "The problem of a residential quarter" [7]. The basis of the book was a study commissioned by the Planning and Land Department of the Moscow City Executive Committee. Apparently, it was part of further work on the Moscow planning project, which was designed by the authors of the book with the participation of S.A. Boldyrev and under the leadership of V.N. Semenov in November 1930.

The authors of the book sought to consider the task of designing a residential quarter comprehensively taking into account the requirements of hygiene, economics, the organization the way of life, etc. Therefore, as the key type of quarter for the study, they chose the "collective building quarter" (residential complexes). For this quarter were made to calculate the optimal percentage of building including residential blocks insolation, number of floors in residential blocks and population density, and also proposed specific indicators which were taken into account in the development of residential development projects. The principles of designing a residential complex, including a nursery, a kindergarten, a canteen, a laundry room, a green and a sports zone, were also proposed.

Most likely, when conducting their research, Moscow architects relied on the work of the German specialist V. Schwagenscheidt, who was a member of the group of E. May and worked at that time in the trust "Standardgorproekt" on projects for new Soviet cities. According to the concept of V. Schwagenscheidt, the urban space was built according to the principle of the hierarchy "residential building — residential complex — residential quarter - residential area - residential city". According to E.V. Konysheva, with his direct participation, the "residential complex" became the basic unit of the city structure in Soviet urban planning in the early 1930s [8]. The works of a German specialist were not published in Russian, but despite the changes that occurred in 1932, their influence on the work of Soviet specialists can be traced up to 1935 .

In 1934, two more works on the design of a residential quarter were published - a book by A.A. Galaktionov and D.M. Sobolev "Residential Quarter. Organization, rules and conditions of planning" [9] and a large text G.V. Sheleikhovsky "Residential quarter, as the lower unit of the city, its elements and standards" [10]. The first was a reflection of the searches conducted by the State Institute of Surveying and Planning of Cities and the Design of Civil Structures of 
the NKVD of the RSFSR (Giprogor), the second was prepared within the walls of the State Institute of Urban Design of the Ukrainian SSR (Giprograd). However, G.V. Sheleikhovsky worked on the order of the AllUnion Council for Communal Services under the Central Executive Committee of the USSR (VSKKH). Both works were based on the idea of a "residential complex" and claimed the role of guidelines for the design of residential development. The work of A.A. Galaktionov and D.M. Sobolev contained instructions on the organization of cultural and public services, of a residential complex, the layout of the quarter and its individual elements. In their calculations, the authors relied on very particular figures for the norm of living space, population density, percentage of development, etc. They believed that changes in indicators in the future (as living conditions in the USSR improve) would not make significant changes to their proposed solutions. G.V. Sheleikhovsky was more cautious in the forecasts, but his work contained many calculations designed to help in this forecasting. However, despite the great work done by the authors, these studies continued to be recommendations for those organizations in which they worked.

Meanwhile, in 1935, with the adoption of the decree of the Council of People's Commissars of the USSR and the Central Committee of the All-Union Communist Party of Bolsheviks "On the Master Plan for the Reconstruction of the City of Moscow", the concept of "residential complex" began to leave in the past. Although the section of the decree on the residential quarter was very general, it recorded a turn towards the development of the quarter with residential houses of individual apartments and the placement of cultural and public services enterprises in or near them. The task of collectivization of the way of life was no longer set, although the principles of locating cultural and consumer services enterprises, based on their availability, were borrowed from developments in the first half of the 1930s. An important innovation was the requirement to increase the number of floors in the building, in connection with which the issues of sanitary and hygienic nature (lighting, insolation, air movement, etc.) became particularly relevant. The large area of the quarters required special techniques for placing green spaces inside the quarter; the proximity of highways to residential development set the task of combating noise and exhaust gases, etc.

Under these conditions, the need to develop norms and standards became increasingly apparent. However, in spite of the already existing developments of design institutes, in spite of studies of the problem of the quarter undertaken by the Academy of Public Utilities, the All-Union Academy of Architecture and, probably, a number of other institutions, a common document has not been developed. Although traces of this work have been preserved in the form of two projects "Norms of city planning" prepared in 1940 by the Academy of Public Utilities and by Giprograd.

\section{COMPOSITIONAL METHODS OF DEVELOPMENT OF RESIDENTIAL QUARTERS: FROM LINE TO RIBBON BUILDING}

Of course, specialists involved in the development of issues design of residential complexes and residential blocks tried to take into account utilitarian and artistic aspects equally, but this was not always possible.

As V.N. Semenov noted in the preface to the book of P.I. Goldenberg and V.I. Dolganov, "we still do not dare to interpret the quarter as a whole and forget about individual construction sites: we still think that houses should be along the street" [11]. P.I. Goldenberg and V.I. Dolganov, speaking about the architectural and planning decision of residential quarters, believed that the layout should "evolve from closed quarters to flow blocks - the organic component of a residential area", i.e. advocated line building ("Fig. 1"). In this regard, it is necessary to answer that for Soviet architects, the appeal to line building was dictated not only by the requirements of insolation. They saw in it a certain symbol of novelty and an interesting compositional method.

After in 1932 Moscow architects were given the task of designing the main avenues of the capital as a matter of priority, the idea of ribbon building regained popularity. However, with some differences from the previous practice, which in 1931 was condemned by V.N. Semenov. The nascent type of development presupposed the placement of residential buildings along the streets, but with gaps that provided ventilation of the intra-quarter spaces, and line building was considered unsuitable for Soviet reality. In the article of 1933 P.I. Goldenberg, justifying the advantages of already perimeter development of the quarter, noted that the location of the buildings "should decorate both the street and the quarter, creating architectural accents either on the streets and intersections, or shifting the architectural focus of attention inside the quarter" [12]. As the advantages of ribbon building, he called a clear architectural composition, economic feasibility and the possibility of creating a significant green areas within the quarter, although the issue of placing public buildings remained controversial.

It is noteworthy that in his works A.A. Galaktionov and G.V. Sheleikhovsky was not so categorical in the choice of ribbon building ("Fig. 2"). From their point of view, it was unwise to neglect sanitary requirements for the sake of aesthetic effect. They saw a way out in the development of such a layout of residential buildings that would correspond to the chosen direction of these buildings relative to the cardinal points [13], [14] 


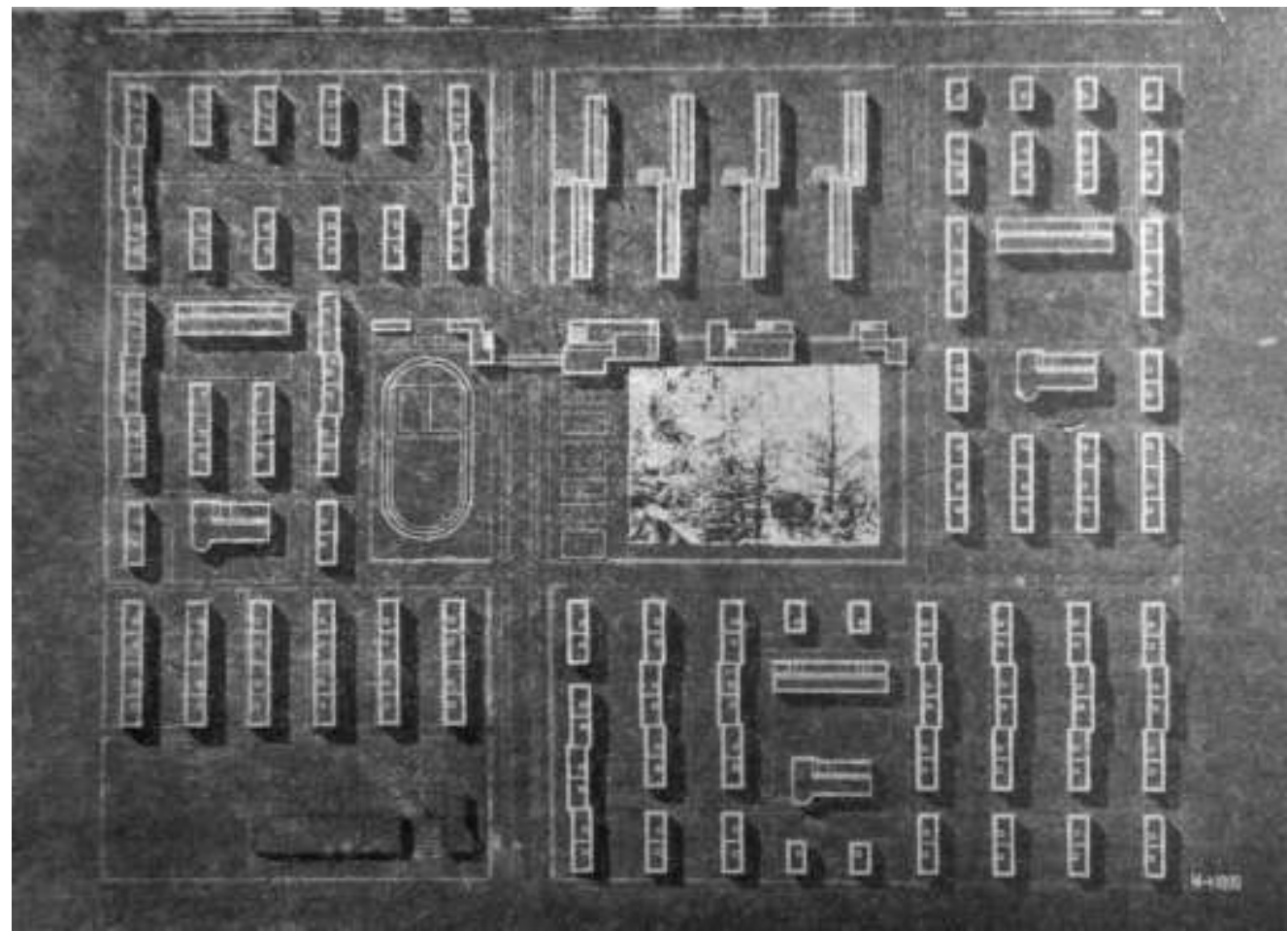

Fig. 1. Line building of the quarter. A variant of the planning from the study of P.I. Goldenberg and V.I. Dolganov.

At the same time, G.V. Sheleikhovsky believed that the rejection of all types of development, except for the ribbon building, would greatly narrow the artistic possibilities of development. However, urban planning went exactly this way, and in 1936 the architect A.M.
Mostakov noted that the rejection of line building and the return to the ribbon building did not provide "the proper height and integrity of the architectural solution," as some architects hoped [15].

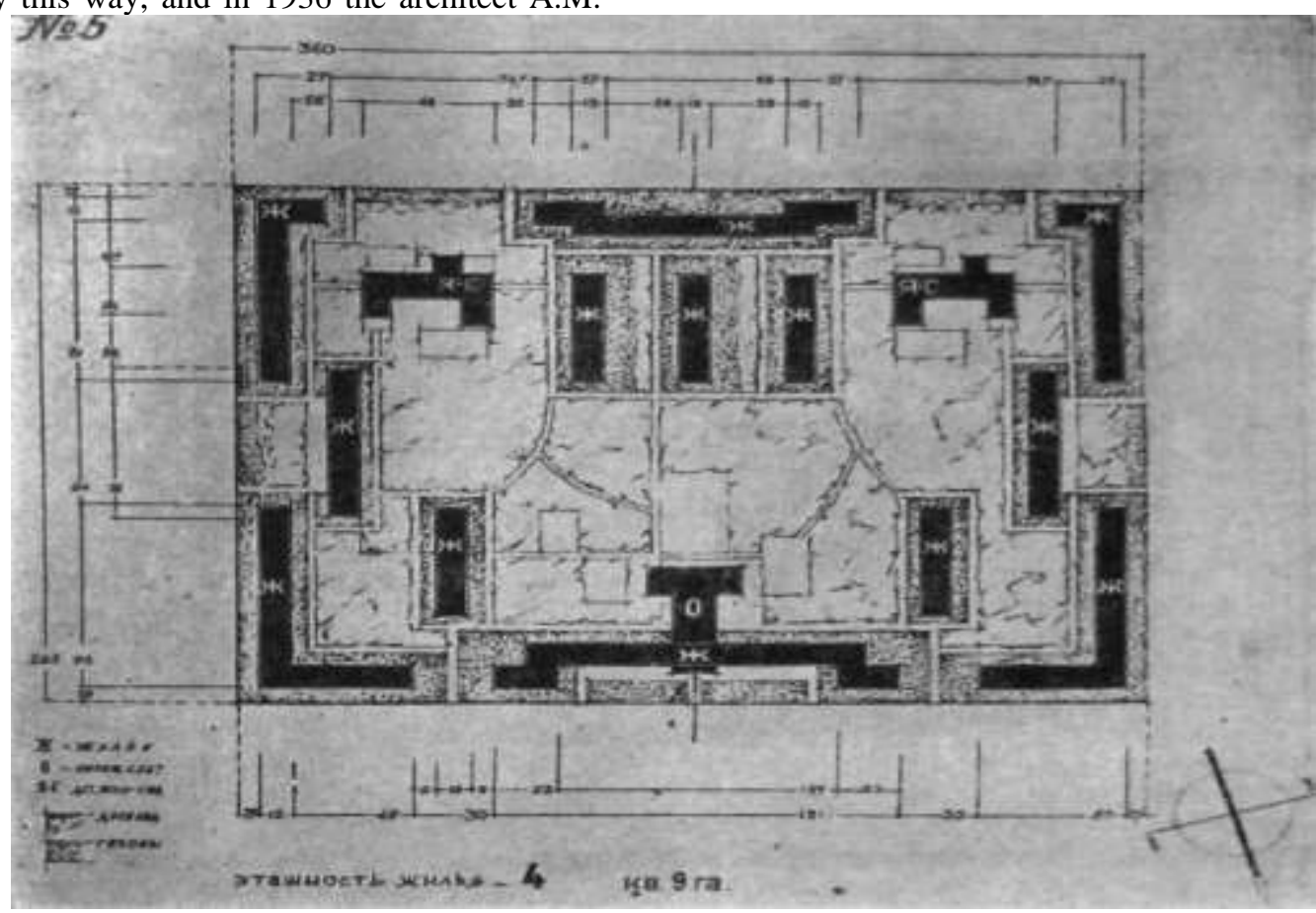

Fig. 2. Ribbon building of the quarter. A variant of the planning from G.V. Sheleikhovsky's article. 
By 1936, it became obvious that it was necessary to look for compositional methods that would allow, on the one hand, to meet the requirement for the architectural design of avenues, and on the other, would not conflict with the internal organization of the quarter. This was extremely difficult, as example of which was suggested by M.Ya. Ginzburg development project of one of the areas of Nizhny Tagil ("Fig. 3"). P.I. Goldenberg called this project "the most interesting and debatable", because he suggested the "quarterless principle of planning". In the project, the courtyards had strict geometric shapes, while the spaces around the houses were formed according to the principle of a free picturesque layout. In other words, the retrieval project M.Ya. Ginzburg contradicted the idea of the architectural design of avenues. The critic believed that this project, containing many controversial decisions, "threatens to become the new "standard", because they have already begun to imitate it even in projects for Moscow [16].

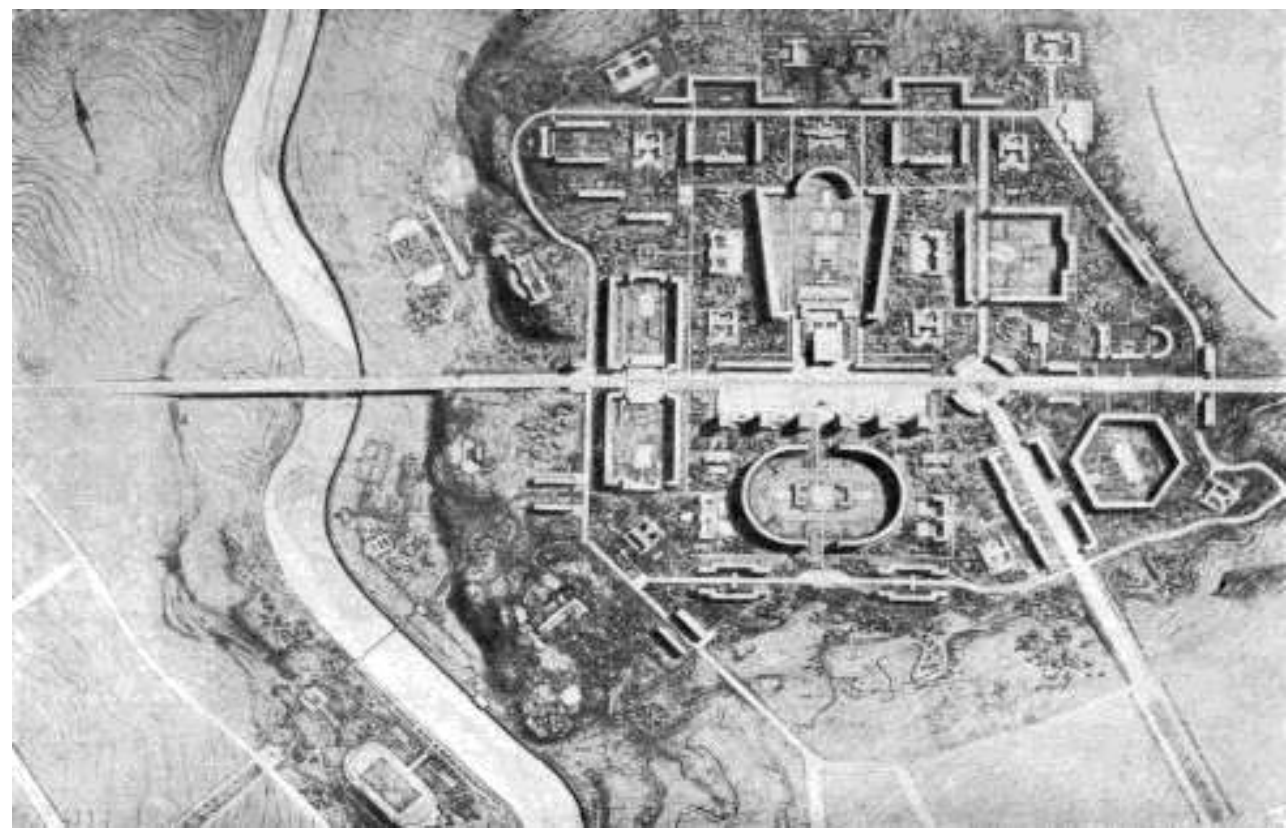

Fig. 3. The development project of the Red Stone district in Nizhny Tagil. Head architect M.Ya. Ginzburg.

Thus, unlike the normative base of the architectural and spatial organization of a residential quarter, where a certain convergence of opinions could be traced, Soviet architects could not come to a common decision when it came to the artistic aspects of design. Moreover, there were those who, following artistic ideals, rejected attempts to comprehend them from the point of view of utilitarian requirements. The result of this was fierce criticism of G.V. Sheleikhovsky, made at the First Congress of Soviet Architects in 1937 in a report by K.S. Alabyan [17].

\section{CONCLUSION}

Summarizing the presented material, it can be argued that the search for the principles of the architectural and spatial organization of the residential quarter in the 1930s was fraught with a number of difficulties and was quite multidirectional in nature. The constantly changing attitudes of the party and government, the need to take into account a complex of very diverse factors from purely utilitarian to aesthetic and ideological, etc. circumstances impeded the systematic and purposeful search for Soviet architects.
In addition, the specialists who dealt with the problem of the residential quarter, although were well acquainted with each other's work, worked in different organizations that did not seek to combine their efforts. As a result, despite a significant number of studies and publications, despite discussions and disputes about the artistic aspects of the designing quarters, the unified principles of the architectural and spatial organization of a residential quarter in the USSR in the 1930s can only be seen in the project schedule of that time.

\section{References}

[1] E.V. Konysheva, A Planning Evolution of an Urban Block during the late 1920s - early 1930s (on example of Urals Cities) in: Bulletin of the South Ural State University. Series: Social Sciences and Humanities, 2011, No. 9 (226), pp. 102-105 [in Russian].

[2] E.V. Konysheva, Testing Area for the Experiment: Western Urban-Planning Innovations in Walter Schwagenscheidt's Projects for Soviet Socialist Cities in: Academia. Architecture and Construction, 2017, No 1, pp. 85-91 [in Russian].

[3] A.V. Vasileva, Residential Area as an Independent Type of Housing in the first third of the 20th century in: Cultural Heritage of Russia, 2018, No. 2, pp. 59-65 [in Russian] 
[4] A.V. Vasileva, Compositional techniques in the organization of residential neighborhoods of Leningrad 1920-1930s in: Science, education and experimental design at the Moscow architectural Institute. Abstracts of reports of the international scientific and practical conference of faculty, young scientists and students, April 8-12, 2019, vol. 1, Moscow, Moscow Institute of architecture, 2019, pp. 371-375 [in Russian].

[5] "On Work at the Reconstruction of the Way of Life" (decree of the Central Committee of the All-Union Communist Party of Bolsheviks, of May 16, 1930) in: Pravda, 1930, No. 146, p. 5 [in Russian].

[6] V.F. Grechukha, Attention to the architecture of new cities in: Construction of Moscow (Stroitel'stvo Moskvy), 1932, No. 8-9, p. 36 [in Russian].

[7] P.I. Goldenberg, V.I. Dolganov, preface by V.N. Semenov, The problem of a residential quarter, Moscow, Leningrad, Management technology, 1931 [in Russian].

[8] E.V. Konysheva, Testing Area for the Experiment..., op. cit., p. 88 [in Russian].

[9] A.A. Galaktionov, D.M. Sobolev, Residential Quarter, Moscow, Gosstroiizdat, 1934 [in Russian].

[10] G.V. Sheleikhovsky, Residential quarter, as the lower link of the city, its elements and standards in: Planning and socialist reconstruction of cities, vol. I, General issues, Moscow, 1934 [in Russian].

[11] P.I. Goldenberg, V.I. Dolganov, preface by V. N. Semenov, op. cit., p. 3.

[12] P.I. Goldenberg, Line or ribbon building of a residential quarter in: Construction of Moscow (Stroitel'stvo Moskvy), 1933, № 1, p. 33 [in Russian].

[13] A.A. Galaktionov, D.M. Sobolev, op. cit., p. 53 [in Russian].

[14] G.V. Sheleikhovsky, op. cit., pp. 171-172 [in Russian].

[15] A.M. Mostakov, Composition of the residential quarter in: Architecture of the USSR, 1936, № 1, p. 17 [in Russian]

[16] P.I. Goldenberg, Experience in the design of new residential areas in: Architecture of the USSR, 1936, No. 9, p. 24 [in Russian].

[17] K.S. Alabyan, Tasks of Soviet architecture, Moscow, 1937, pp. 27-28 [in Russian]. 